\title{
Effects of soil fertilization on the allocation of net primary productivity in tropical rainforests of Chocó, Colombia
}

\author{
Harley Quinto-Mosquera ${ }^{1}$, Hamleth Valois-Cuesta ${ }^{1}$, and Flavio Moreno ${ }^{2, *}$ \\ 1 Programa de Biología. Facultad de Ciencias Naturales, Universidad Tecnológica del Chocó “Diego Luis \\ Córdoba", 22 N¹8B-10, Quibdó, Colombia; hquintom@gmail.com \\ 2 Departamento de Ciencias Forestales, Facultad de Ciencias Agrarias, Universidad Nacional de Colombia \\ Sede Medellín, Medellín, Colombia; fhmoreno@unal.edu.co \\ * Correspondence: hquintom@gmail.com; Tel.: +57 3218154729; https://orcid.org/0000-0001-5989-4334
}

\begin{abstract}
NPP) of the world. Hypotheses about the effect of edaphic nutrient contents, especially the availability of $\mathrm{P}$, propose that they limit NPP of tropical forests or promote the redistribution of its above and belowground components. However, these hypotheses have not been tested experimentally in highly rainy tropical forests. To test such hypotheses, the effects of soil fertilization on the above and belowground NPP were evaluated in forests of two localities of Chocó (Colombia), one of the rainiest regions of the world. Five fertilization treatments (N, P, K, NPK and Control) were applied, and the above and belowground NPP were determined in permanent plots. There were no significant effects of treatments on total NPP; only the application of N significantly increased litter NPP. Additionally, a redistribution of the above and belowground NPP was found with the application of $\mathrm{P}$, which increased the proportion of fine roots and litter, and decreased the woody components of forest NPP. This change of carbon allocation is interpreted as an ecophysiological mechanism to capture additional nutrients in soils with very low content of available P.
\end{abstract}

Keywords: Biogeographic Chocó; Carbon balance; Nutritional limitation; Nitrogen; Phosphorus; Potassium

\section{Introduction}

Lowland tropical rainforests (TRF) are considered as the terrestrial ecosystems with the highest net primary productivity (NPP) in the world [ $1,2, \underline{3}]$. However, most of them are located on poor soils, with extreme acidity and aluminum (Al) toxicity [ $\underline{4}, \underline{5}]$. Furthermore, soil fertility, especially nitrogen $(\mathrm{N})$, phosphorus $(\mathrm{P})$ and potassium $(\mathrm{K})$ concentrations [ [ $]$ are considered among the main factors that determine the NPP of TRF [ $[\underline{8}, \underline{q}]$.

Although nutrient availability limits NPP of TRF []], the effect of each nutrient on the above and belowground components of NPP is different $[\underline{10}, \underline{8}, \underline{11}, \underline{12}]$. It has been hypothesized that edaphic content of available $\mathrm{P}$ is the main limiting factor of aboveground NPP in these ecosystems ( $(\mathbf{7})$, because P loss by leaching and its immobilization in Fe and $\mathrm{Al}$ oxides reduce its availability for plants $[\underline{13}, \underline{14}]$. Likewise, the soil availability of $\mathrm{K}$ has been considered to limit the NPP at a global level, but it has been little evaluated in tropical forests $[\underline{16}, \underline{17}]$. Contrarily, soil $\mathrm{N}$ is considered less limiting because its availability tends to be high $[\underline{7} \underline{15}, \underline{8}]$.

Nutrient limitation of NPP in TRF has been poorly tested through field experiments; for this reason, the current debate about this issue needs to be fed with new studies. To experimentally test the hypothesis of nutrient limitation, it is necessary to add fertilizers or organic amendments and evaluate their effects on the above and belowground components of NPP [18]. The few studies that have evaluated this limitation in TRF show that the factorial application of N, P and K generates variable effects (i.e. positive, null and / or negative) on the different components of NPP [19]. However, the effects on total NPP have 
not been yet evaluated and consequently, the nutritional limitation of NPP has been poorly proven experimentally. Poorter et al. (20) suggest that Instead of nutrient limitation, forest NPP probably depends on the "functional equilibrium" of many limiting factors (such as nutrients, water, light, and $\mathrm{CO}_{2}$ ), which affect the NPP allocation and biomass.

Most of the fertilization experiments in low altitude tropical forests have been carried out in forests with rainfall less than $5000 \mathrm{~mm}$ per year; for this reason, the ideas of what happens in forests where rainfall is greater, lack almost entirely empirical evidence and are fundamentally speculative. For example, it is believed that above this range of precipitation the NPP tends to decrease drastically [21]. Rains usually cause nutrient losses through leaching and runoff $[\underline{22}, \underline{23}, \underline{24}]$, lower foliar concentration of nutrients, and a decrease of $\mathrm{N}$ mineralization and nitrification rates $[\underline{25}, 26,27]$. Therefore, a greater nutritional limitation of the ecosystem NPP is expected under such conditions.

To test the hypothesis of nutritional limitation of NPP in tropical forests with high rainfall, two TRF were selected in the biogeographic Chocó region, which has one of the highest rainfalls in the world ( $\approx 10000 \mathrm{~mm}$ annually) [28] , where a fertilization experiment with $\mathrm{N}, \mathrm{P}$, and $\mathrm{K}$ was carried out to test the following hypotheses: 1) the application of nutrients increases the total NPP of tropical rain forests. 2) the application of nutrients generates a redistribution of NPP between aboveground and belowground components of rainforests. In particular, the study aims to answer the following questions: 1) What effect does the application of N, P and K have on the NPP in these forests, and does a redistribution of NPP among plant components occur with the application of these nutrients?. 2) Is NPP really limited in these ecosystems and if so, which nutrient is the most limiting?

\section{Materials and Methods}

\subsection{Study Area}

The present study was conducted in tropical rain forests located in the localities of Pacurita (municipality of Quibdó) and Opogodó (municipality of Condoto), department of Chocó, Colombia. These localities belong to the geomorphological unit of Tertiary sedimentary hills of low altitudes, which are formed by sedimentary rocks composed of sandy arcillolites, sandstones and limestones [11]. The specific edaphic and structural characteristics of the Opogodó and Pacurita forest plots are detailed in Table $\underline{1}$. In Opogodó the sampling was carried out in three permanent plots of one ha each $(100 \times 100 \mathrm{~m})$, established in 2013 in a primary forest located inside the facility of the Technological University of Chocó "Diego Luis Córdoba". In Pacurita, the study was carried out in two permanent plots of a forest located on the left margin of the road Quibdó - Pacurita. In both locations, the sampling was carried out in well-preserved primary forests.

\subsection{Methods}

Experimental design: we used a randomized complete block design with five fertilization treatments (N, P, K, NPK and Control) and five repetitions [29]. To do this, each plot was divided into five experimental units of $20 \times 100 \mathrm{~m}(0.2 \mathrm{ha})$, separated by a strip $2 \mathrm{~m}$ wide to reduce the risk of nutrient contamination from neighbor plots. In each experimental unit a fertilization treatment was applied randomly. Each experimental unit was divided into five subplots of $20 \times 20 \mathrm{~m}$ to facilitate the control of fertilizer application and the subsequent collection of NPP data. Subplots were subdivided into squares of $10 \times 10$ $\mathrm{m}$, where soil samples were taken and NPP was measured. 
Table 1. Edaphic and structural parameters of five permanent plots in forests of Chocó, Colombia.

\begin{tabular}{|c|c|c|c|c|c|}
\hline Edaphic parameters & Opogodó I & Opogodó II & Opogodó III & Pacurita I & Pacurita II \\
\hline $\mathrm{pH}$ & 4.74 & 5.15 & 5.04 & 3.90 & 4.16 \\
\hline Aluminium $\left(\mathrm{cmol} \mathrm{kg}^{-1}\right)$ & 0.13 & 0.13 & 0.12 & 0.94 & 0.95 \\
\hline Organic matter $(\%)$ & 14.30 & 10.06 & 11.48 & 4.93 & 3.21 \\
\hline Total Nitrogen (\%) & 0.72 & 0.56 & 0.57 & 0.25 & 0.16 \\
\hline Phosphorus (ppm) & 1.83 & 1.08 & 1.08 & 1.02 & 1.71 \\
\hline Potassium $\left(\mathrm{cmol} \mathrm{kg}^{-1}\right)$ & 0.19 & 0.27 & 0.24 & 0.15 & 0.20 \\
\hline Calcium $\left(\mathrm{cmol} \mathrm{kg}^{-1}\right)$ & 0.25 & 0.39 & 0.53 & 0.35 & 0.36 \\
\hline Magnesium $\left(\mathrm{cmol} \mathrm{kg}^{-1}\right)$ & 0.33 & 0.27 & 0.25 & 0.19 & 0.16 \\
\hline Cation exchange capacity $\left(\mathrm{cmol} \mathrm{kg}^{-1}\right)$ & 0.91 & 1.05 & 1.13 & 1.62 & 1.67 \\
\hline Clay $(\%)$ & 0.52 & 0.96 & 1.65 & 20.00 & 17.04 \\
\hline Silt (\%) & 12.96 & 13.20 & 13.57 & 28.24 & 28.00 \\
\hline Sand $(\%)$ & 86.52 & 85.84 & 84.78 & 51.76 & 54.96 \\
\hline \multicolumn{6}{|c|}{ Structural parameters (trees with $\mathrm{DBH}>10 \mathrm{~cm}$ ) } \\
\hline Abundance (ind. ha ${ }^{-1}$ ) & 954 & 705 & 635 & 913 & 979 \\
\hline Aboveground biomass $\left(t_{\text {ha-1 }}\right)$ & 305.70 & 166.25 & 175.35 & 335.90 & 201.49 \\
\hline Mean diameter ( $\mathrm{cm} / \mathrm{ind})$ & 15.50 & 17.12 & 17.94 & 16.91 & 15.07 \\
\hline Mean height (m/ind) & 15.12 & 16.00 & 16.36 & 15.95 & 14.93 \\
\hline
\end{tabular}

The fertilizers were applied broadcast in doses similar to those used in other experiments carried out in low altitude tropical rain forests [30, 31]. The annual dose of each fertilizer was applied in four equal doses applied quarterly starting in August 2014 and

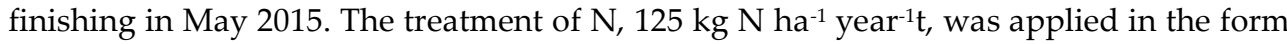
of urea $\left(\left(\mathrm{NH}_{2}\right) 2 \mathrm{CO}\right)$; for the treatment of $\mathrm{P}, 50 \mathrm{~kg} \mathrm{P}^{-1} \mathrm{year}^{-1}$, we used phosphate rock $\left(\mathrm{H}_{3} \mathrm{PO}^{4}\right)$; for the treatment of $\mathrm{K}, 50 \mathrm{~kg} \mathrm{~K}^{-1}$ year $^{-1}$, we applied potassium chloride $(\mathrm{KCl})$ ); in the treatment of NPK, each of the previous doses were applied together; and in the Control no fertilizers were applied.

Measurement of tree diameters and heights: Two censuses of the plots were carried out previously to the application of fertilizations treatments, in the month of August 2013 and 2014 and then a third census, after fertilization treatments in August 2015, to individuals with diameter at breast height $(\mathrm{DBH}) \geq 10 \mathrm{~cm}$. In each census the living, dead, and recruited individuals (i.e. those that reached DAP $\geq 10 \mathrm{~cm}$ ) were recorded. For all trees measured the morpho species were identified up to the maximum taxonomic level possible (NN, species, genus, botanical family) in the Herbarium of the Technological University of Chocó "D.L.C." "Herbario Chocó". This identification was made using the specialized keys of Gentry (르).

All measurements were made in areas free of knots, buttresses or branches. We marked with yellow paint the perimeter of the tree trunk where the diameter was measured in order to identify it in subsequent measurements. All trees measured were also marked with aluminum plates. Heights were measured in the $40 \%$ of trees with Suunto clinometer at fixed distances of 15 and $20 \mathrm{~m}$ from the tree; likewise, heights of the smallest trees (heights less than 10-15 meters) were measured with a graduated rod. For the remaining $60 \%$ of trees, heights were estimated with equations 1 and 2 [33] based on the ecological groups of species. 
Total height of non-pioneer species $(\mathrm{m})=6.28+0.607^{*} \mathrm{DBH}$

Total height of pioneer species $(\mathrm{m})=7.422+0.411^{*} \mathrm{DBH}$

Measurement of fine litter and fine root production: a litter trap $(1 \times 0.5 \mathrm{~m})$ was installed $1 \mathrm{~m}$ above the ground in the center of the $20 \times 20 \mathrm{~m}$ sampling subplot. In total, 125 traps were installed for fine litter sampling, which was collected every month for one year. To measure the NPP of fine roots, we used the ingrowth core method [ $\underline{34}$ ] modified by Moreno-Hurtado ( $\underline{35})$. In this method, a volume of soil is extracted and the soil removed; then, this volume of root-free soil is returned back to the orifice previously left on the forest floor. Cores are left in the soil for a certain period of time allowing the growth of fine roots; then, cores are extracted, the roots removed and the NPP of fine roots is determined [ $\underline{34}, \underline{36}]$. In the modified method [ㅌ5], instead of placing the root-free soil in a mesh bag to be returned back into the hole, it was directly deposited in the hole without any container, so that it is completely in contact with the surrounding soil, and there are no obstacles that can limit the root growth into the core. To ease the sample retrieval, three thick metallic wires located on the walls of the hole were used. The purpose of these wires is to align the filling space and to guide the retrieval of soil samples exactly in the hole where the free-root soil was introduced.

The modified ingrowth cores were located in the center of each $10 \times 10 \mathrm{~m}$ square; for this purpose, two soil samples $(0-10 \mathrm{~cm}$ and $10-20 \mathrm{~cm}$ deep) were extracted with a Eijkelkamp ${ }^{\circledR}$ soil auger $(8 \mathrm{~cm}$ diameter and $15 \mathrm{~cm}$ long). Fine roots (FR) (with diameters $\leq 5 \mathrm{~mm})$ were manually separated in the field using plastic trays and sieves (0.5 and 1.0 $\mathrm{mm})$. After extracting FR, the soil was introduced back into the holes, and roots were transported to the laboratory for processing. This procedure was performed every three months for one year; in each sampling date 100 soil cores were evaluated at two depths per plot, which resulted in a total of 1000 FR samples per field campaign. In the laboratory, the FR sampled quarterly were washed and sieved $(0.5$ and $1 \mathrm{~mm})$ to remove the remaining soil. Subsequently, FR were oven-dried $\left(70^{\circ} \mathrm{C}\right.$ for 48 hours) and weighed in an analytical balance $(0.0001 \mathrm{~g})$. The NPP of fine roots was determined as the value accumulated over time and expressed in $\mathrm{tha}^{-1}$ year $^{-1}$.

Data analysis: For the estimation of tree aboveground biomass (AB) we reviewed seven models generated with information from tropical wet forests of different locations of the world [ $\underline{37}, \underline{38}, \underline{39}]$; the model from Chave et al. (포) (Equation 3) was chosen because the $\mathrm{AB}$ estimated with that model had higher average correlation coefficient with the $\mathrm{AB}$ estimated with the other models, according to the evaluation made by Quinto-Mosquera and Moreno ( $\underline{33}$ ); in addition, the model was chosen because it includes as predictors three key variables of wood biomass ( $\mathrm{DBH}$, total height, and wood density) [3]. The belowground biomass in coarse roots (BB, equation 8$)$ was estimated as $21 \%$ of $\mathrm{AB}[\underline{12}]$.

$$
\begin{aligned}
& \mathrm{AB}(\mathrm{kg})=\operatorname{Exp}\left(-2.557+0.94^{*} \ln \left(\mathrm{ei}^{*} \mathrm{DBH}^{2 *} \mathrm{H}\right)\right) . \\
& \mathrm{BB}(\mathrm{kg})=0.21^{*} \mathrm{AB}
\end{aligned}
$$

Where $\mathrm{AB}$ is the aboveground biomass and $\mathrm{BB}$ is the belowground biomass of trees in $\mathrm{kg}, \mathrm{DBH}$ is the diameter, ln is natural logarithm, $\mathrm{H}$ is the total height, and @i is the wood density. The increase in forest biomass was calculated from the information of $A B$ and $B B$ of each sample and measurement. For the estimation of wood density, we used the values published in two databases, generated mainly in forests of the Amazon [ $\underline{38}$ ] and in tropical forests of different regions of the world [37]. If any species or genus found in the plots was not reported in these databases, the average wood density of the respective genus or family was used; for the taxonomically undetermined individuals, the average wood density of the plot was used.

Total NPP and its components were determined with equations $5-8[\underline{40}, \underline{41}]$ : 
$\mathrm{NPP}=$ NPPaboveground + NPPbelowground

NPPaboveground $=\triangle \mathrm{ABs}$ survivors $+\triangle \mathrm{ABrecruited}+$ NPPlitterfall

NPPaboveground wood $=\triangle \mathrm{ABsurvivors}+\triangle \mathrm{ABrecruited}$

NPPbelowground $=\triangle B$ Bsurvivors $+\triangle B B$ recruited + NPPfine roots

Where, $\triangle \mathrm{ABsurvivor}$ is the increase in aerial biomass $(\mathrm{AB})$ of surviving trees determined as the final $\mathrm{AB}$ (second measurement) minus the initial $\mathrm{AB}$ (first measurement) of each surviving tree; $\triangle \mathrm{ABrecruited}$ is the increase in $\mathrm{AB}$ of trees recruited between samplings, calculated as the $\mathrm{AB}$ of the recruited trees (new individuals that reached $\mathrm{DBH} \geq 10$ $\mathrm{cm}$ ) recorded in the second measurement minus the $\mathrm{AB}$ of an individual of $10 \mathrm{~cm}$ of $\mathrm{DBH}$. The increase of coarse root biomass $(\triangle B B$, equation 8$)$ was determined similarly to the increase of $\mathrm{AB}$ of equation 6. NPPfine roots is the production of fine roots determined by

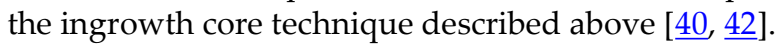

We used a General Linear Model of Mixed Effects to evaluate the effect of soil fertilization treatments and the locality on total NPP and its components; the effect of the interaction between the two factors evaluated (fertilization $\times$ locality) was also included in the model. When the contrasts between levels of the factors and its interactions were significant, a Tukey HSD test was used for the post hoc contrasts. The homoscedasticity of the data was checked through the Shapiro-Wilk normality test and the homogeneity of variances through the Levenne test. When data were not homoscedastic, they were transformed to $\log (x+0.5)$ to adjust their normality. However, untransformed data (mean \pm 2 standard error) are shown in the text, tables and figures. All statistical analyzes were performed in the R statistical programming environment 2.15 [43] , using the package "nlme" Version 3.1-137 [녀].

\section{Results}

Differences of NPP between localities: the total NPP did not vary significantly between localities or fertilization treatments (Table $\underline{2}$, Figure $\underline{1}$ ). However, when evaluating each component of NPP independently, a significant effect of the locality was evidenced, particularly on fine litter NPP, fine root NPP, belowground NPP and labile NPP, with higher values in Opogodó than in Pacurita. No other components showed significant variations between localities (Table 2, Figure 1). Fertilization treatments had significant effect on fine litter NPP only, with higher values as a result of the joint or separate application of N, P and K (Table $\underline{2}$ ).

NPP components and ratios: The locality had a significant effect on the ratio labile NPP / total wood NPP, fine litter NPP / fine roots NPP, and litter NPP / aboveground wood NPP. A significant effect of the localities was also observed for the percentage of labile NPP and litterfall NPP. In general, the proportional production of these components was greater in Opogodó (Table $\underline{3}$ ). On the other hand, when evaluating the effect of fertilization treatments, the application of $\mathrm{N}$ had a significant effect on the ratio litter NPP / fine roots NPP as compared with the Control. Significant effects were also found among fertilization treatments for the percentages of belowground NPP, aboveground NPP, labile NPP, fine root NPP and fine litter NPP (Table $\underline{3}$ ). In particular, the application of P increased the percentages of belowground NPP, fine roots NPP, labile NPP, and litter NPP, with respect to the Control (Table $\underline{3}$ ). Similarly, the application of NPK increased the percentages of Labile, Fine roots and litterfall NPP, and decreased the percentage of aboveground NPP.

The variations found among treatments in the proportional ratios of aboveground NPP / belowground NPP, litter NPP / fine roots NPP, and the percentages of belowground 
and aboveground NPP, were not independent of the locality. A significant effect of the interaction between the levels of these two factors was found, with greater proportional aboveground as compared with belowground NPP in Opogodó than in Pacurita, especially with the application of $\mathrm{N}$; the same relation was greater in Pacurita with the application of P and K (Figure 2). The ratio litter NPP / fine roots NPP was higher in Opogodó than in Pacurita, especially when applying N or NPK (Figure 2). On the other hand, the percentage of belowground NPP and of aboveground NPP showed variations between localities when nutrients were applied separately (Figure $\underline{3}$ ).

Table 2. Effects of the localities and nutrient treatments on NPP in tropical rain forests of the Chocó region. Colombia.

\begin{tabular}{|c|c|c|c|c|c|c|c|c|c|}
\hline \multirow[b]{2}{*}{ Factors } & \multicolumn{9}{|c|}{ Net primary productivity } \\
\hline & $\begin{array}{c}\text { Aboveground } \\
\text { wood }\end{array}$ & $\begin{array}{l}\text { Coarse } \\
\text { roots }\end{array}$ & $\begin{array}{l}\text { Total } \\
\text { wood }\end{array}$ & Litterfall & Fine roots & $\begin{array}{c}\text { Total } \\
\text { aboveground }\end{array}$ & $\begin{array}{c}\text { Total } \\
\text { belowground }\end{array}$ & $\begin{array}{l}\text { Total } \\
\text { labile }\end{array}$ & $\begin{array}{l}\text { Total } \\
\text { NPP }\end{array}$ \\
\hline \multicolumn{10}{|l|}{ Localities } \\
\hline Opogodó & $9.7 \pm 0.81$ & $1.61 \pm 0.17$ & $11.3 \pm 0.98$ & $4.83 \pm 0.13$ & $4.16 \pm 0.16$ & $14.5 \pm 0.85$ & $5.77 \pm 0.23$ & $8.99 \pm 0.22$ & $20.3 \pm 1.02$ \\
\hline Pacurita & $9.5 \pm 0.97$ & $1.46 \pm 0.20$ & $11.0 \pm 1.17$ & $3.13 \pm 0.10$ & $3.45 \pm 0.15$ & $12.6 \pm 0.99$ & $4.91 \pm 0.24$ & $6.58 \pm 0.18$ & $17.5 \pm 1.19$ \\
\hline$L M E\left(F_{1.115}\right)$ & 0.006 & 0.47 & 0.05 & $60.1^{* * *}$ & $8.09^{* *}$ & 1.93 & $6.19^{*}$ & $64.3^{* * *}$ & 2.98 \\
\hline \multicolumn{10}{|l|}{ Trataments } \\
\hline $\mathrm{N}$ & $9.5 \pm 1.00$ & $1.53 \pm 0.20$ & $11.1 \pm 1.19$ & $4.56 \pm 0.31 \mathrm{a}$ & $3.49 \pm 0.20$ & $14.1 \pm 1.08$ & $5.02 \pm 0.28$ & $8.06 \pm 0.38$ & $19.1 \pm 1.26$ \\
\hline $\mathrm{P}$ & $7.4 \pm 1.57$ & $1.13 \pm 0.31$ & $8.5 \pm 1.87$ & $4.33 \pm 0.25 a$ & $4.11 \pm 0.24$ & $11.7 \pm 1.63$ & $5.24 \pm 0.37$ & $8.44 \pm 0.39$ & $16.9 \pm 1.93$ \\
\hline $\mathrm{K}$ & $12.1 \pm 1.90$ & $2.12 \pm 0.40$ & $14.2 \pm 2.30$ & $3.84 \pm 0.23 c$ & $3.93 \pm 0.34$ & $16.0 \pm 1.96$ & $6.05 \pm 0.52$ & $7.77 \pm 0.50$ & $22.0 \pm 2.36$ \\
\hline NPK & $8.7 \pm 1.04$ & $1.34 \pm 0.24$ & $10.1 \pm 1.28$ & $4.20 \pm 0.29 b$ & $4.24 \pm 0.25$ & $12.9 \pm 1.11$ & $5.58 \pm 0.32$ & $8.44 \pm 0.38$ & $18.5 \pm 1.35$ \\
\hline Control & $10.2 \pm 1.17$ & $1.63 \pm 0.22$ & $11.8 \pm 1.38$ & $3.83 \pm 0.20 \mathrm{c}$ & $3.61 \pm 0.24$ & $14.0 \pm 1.23$ & $5.24 \pm 0.37$ & $7.44 \pm 0.35$ & $19.3 \pm 1.54$ \\
\hline $\operatorname{LME}\left(F_{4.115}\right)$ & 1.58 & 1.61 & 1.59 & $3.40^{*}$ & 1.35 & 1.18 & 1.09 & 1.51 & 1.13 \\
\hline \multicolumn{10}{|c|}{ Localities $\times$ Trataments } \\
\hline $\operatorname{LME}\left(F_{4.115}\right)$ & 0.52 & 0.28 & 0.55 & 0.70 & $2.77^{*}$ & 0.53 & 1.98 & 1.27 & 0.50 \\
\hline
\end{tabular}

$L M E$ is Linear Mixed-Effects Models. $F$ values with asterisks indicate statistically significant differences ${ }^{*} \mathrm{P}<0.05 .{ }^{* *} \mathrm{P}<0.01 .{ }^{* * *} \mathrm{P}<0.0001$. . Different letters indicate statistically significant differences between treatment levels.

\section{Discussion}

Effects of fertilization on the total NPP of the forest. The soil fertilization treatments of N, P, K and NPK applied to the soil had no significant effect on the total NPP of the tropical rainforests evaluated. In particular, there was no significant influence of $\mathrm{P}$ application, which disproves the hypothesis of P limitation on forest NPP $[\underline{7} \underline{12}, \underline{8}]$. Likewise, there was no evidence on N limitation of NPP, as suggested by several investigations [ $\underline{30}, \underline{45}]$. Apparently the total NPP in mature forests is little influenced by the application and / or unforeseen increased availability of nutrients after two years of fertilization and even in periods of fertilization greater than ten years $[\underline{31}, \underline{46}]$. Then, why total NPP of the rainforests studied does not seem limited by the N, P and K added? Among the reasons that might explain this lack of effect are the following:

1) Structure and diversity of vegetation: the high diversity of tree species in the rainforests of the biogeographic Chocó [ $\underline{47} \underline{48}]$, which differ in age, size, wood density, nutrient content, light requirements, photosynthesis and growth rates, might lead to variation in the amount of the most limiting nutrients for the production of organic matter [ $\underline{49}, \underline{11}]$. In particular, differences in life histories of plants lead to differential nutritional requirements and responses to fertilization $[\underline{18}, \underline{50}]$; also, it is known that small trees respond to 
fertilization differently than large trees $[\underline{31}, \underline{51}, \underline{49}, \underline{11}]$. This situation would make it difficult to prove effects of the application of nutrients on NPP at the ecosystem level in low altitude tropical forests $[\underline{4}, \underline{46}]$.
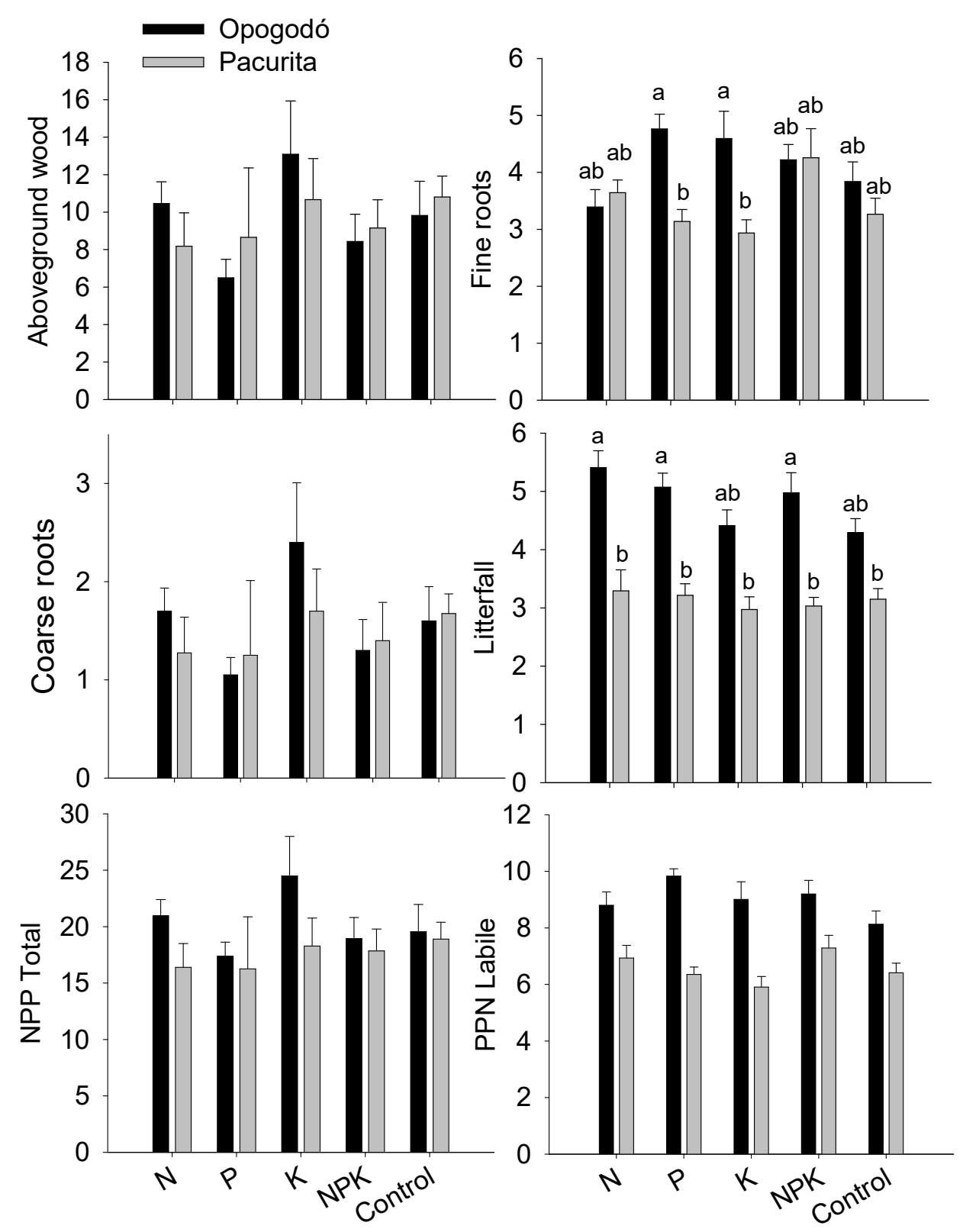

Trataments

Figure 1. Effects of the localities $\times$ nutrient interaction on components of NPP in tropical rain forests of the Chocó region, Colombia. Different letters indicate statistically significant differences between treatment levels $(\mathrm{P}<0.05)$. 
Table 3. Effects of the localities and nutrient treatments on the ratios among components of NPP in tropical rain forests of the Chocó region, Colombia.

\begin{tabular}{|c|c|c|c|c|c|c|c|c|c|}
\hline \multirow{4}{*}{ Factors } & \multicolumn{9}{|c|}{ Net primary productivity } \\
\hline & \multirow{3}{*}{$\begin{array}{r}\text { Aboveground } \\
\text { NPP/Belowground } \\
\mathrm{NPP}\end{array}$} & \multirow{3}{*}{$\begin{array}{r}\text { Labile } \\
\text { NPP/Total } \\
\text { Wood NPP }\end{array}$} & \multirow{3}{*}{$\begin{array}{r}\text { Literfall } \\
\text { NPP/Fine } \\
\text { roots NPP }\end{array}$} & \multirow{3}{*}{$\begin{array}{r}\text { Literfall } \\
\text { NPP/Aboveground } \\
\text { wood NPP }\end{array}$} & \multirow{3}{*}{$\begin{array}{r}\% \\
\text { Belowground } \\
\text { NPP }\end{array}$} & \multirow{3}{*}{$\begin{array}{r}\% \\
\text { Aboveground } \\
\text { NPP }\end{array}$} & \multirow{3}{*}{$\begin{array}{r}\% \text { Labile } \\
\text { NPP }\end{array}$} & \multirow{3}{*}{$\begin{array}{r}\% \text { Fine } \\
\text { roots NPP }\end{array}$} & \multirow{3}{*}{$\begin{array}{r}\text { \% Litterfall } \\
\text { NPP }\end{array}$} \\
\hline & & & & & & & & & \\
\hline & & & & & & & & & \\
\hline \multicolumn{10}{|l|}{ Localities } \\
\hline Opogodo & $2.54 \pm 0.10$ & $1.21 \pm 0.10$ & $1.28 \pm 0.06$ & $0.71 \pm 0.05$ & $30.1 \pm 0.90$ & $69.9 \pm 0.90$ & $50.1 \pm 1.95$ & $23.4 \pm 1.19$ & $26.7 \pm 1.01$ \\
\hline Pacurita & $2.52 \pm 0.10$ & $0.93 \pm 0.10$ & $0.98 \pm 0.05$ & $0.51 \pm 0.06$ & $29.4 \pm 0.80$ & $70.5 \pm 0.80$ & $43.2 \pm 2.19$ & $22.4 \pm 1.19$ & $20.8 \pm 1.28$ \\
\hline LME (F1.115) & 0.07 & $4.82^{*}$ & $9.05^{* *}$ & $6.92^{* *}$ & 0.26 & 0.26 & $5.74 *$ & 0.37 & $13.8^{* *}$ \\
\hline \multicolumn{10}{|l|}{ Trataments } \\
\hline $\mathrm{N}$ & $2.86 \pm 0.19 a$ & $1.05 \pm 0.18$ & $1.42 \pm 0.13 a$ & $0.65 \pm 0.11$ & $27.4 \pm 1.34 b$ & $72.6 \pm 1.34 \mathrm{a}$ & $45.6 \pm 2.97 b$ & $20.2 \pm 1.71 \mathrm{c}$ & $25.4 \pm 1.83 b$ \\
\hline $\mathrm{P}$ & $2.18 \pm 0.15 b$ & $1.36 \pm 0.16$ & $1.11 \pm 0.07 \mathrm{~b}$ & $0.76 \pm 0.09$ & $33.0 \pm 1.44 a$ & $67.0 \pm 1.44 b$ & $56.4 \pm 3.37 a$ & $27.8 \pm 1.91 a$ & $28.7 \pm 1.87 a$ \\
\hline $\mathrm{K}$ & $2.61 \pm 0.19 b$ & $0.96 \pm 0.15$ & $1.06 \pm 0.07 \mathrm{c}$ & $0.53 \pm 0.07$ & $29.5 \pm 1.50 b$ & $70.5 \pm 1.50 \mathrm{a}$ & $42.8 \pm 3.74 b$ & $21.7 \pm 2.12 c$ & $21.1 \pm 1.85 c$ \\
\hline NPK & $2.32 \pm 0.13 b$ & $1.20 \pm 0.16$ & $1.06 \pm 0.09 c$ & $0.67 \pm 0.10$ & $31.2 \pm 1.15 b$ & $68.8 \pm 1.15 b$ & $49.6 \pm 3.03 a$ & $24.9 \pm 1.72 b$ & $24.7 \pm 1.95 b$ \\
\hline Control & $2.71 \pm 0.14 a$ & $0.95 \pm 0.17$ & $1.15 \pm 0.08 b$ & $0.52 \pm 0.08$ & $28.1 \pm 1.32 b$ & $71.9 \pm 1.32 \mathrm{a}$ & $42.3 \pm 2.84 b$ & $20.5 \pm 1.76 c$ & $21.8 \pm 1.52 c$ \\
\hline LME (F4.115) & $3.46^{*}$ & 1.32 & $6.78^{* *}$ & 2.09 & $3.05^{*}$ & $3.05^{*}$ & $3.38^{*}$ & $3.14^{*}$ & $2.99^{*}$ \\
\hline \multicolumn{10}{|c|}{ Localities $\times$ Trataments } \\
\hline$L M E$ (F4.115) & $2.52^{*}$ & 1.07 & $2.92^{*}$ & 1.24 & $2.67^{*}$ & $2.67^{*}$ & 0.51 & 1.59 & 0.64 \\
\hline
\end{tabular}

$L M E$ is Linear Mixed-Effects Models. $F$ values with asterisks indicate statistically significant differences ${ }^{*} \mathrm{P}<0.05 .{ }^{* *} \mathrm{P}<0.01 .{ }^{* * *} \mathrm{P}<0.0001$. Different letters indicate statistically significant differences between treatment levels $(\mathrm{P}<0.05)$.

2) Biological, chemical and physical soil processes: The added nutrients can be fixed and immobilized by soil microorganisms [르] , by inorganic absorption processes and / or chemical solubility phenomena $[\underline{4}, \underline{53}, \underline{54}]$; particularly, the edaphic $\mathrm{P}$ can react with oxides of $\mathrm{Fe}$ and $\mathrm{Al}$, which are not available for plants $[\underline{13}, \underline{55}]$. In addition, the applied nutrients can be leached by the frequent rains $[\underline{22}, \underline{26}, \underline{24}]$ of the study area, which range between 8000 and $10000 \mathrm{~mm}$ per year [28], and / or be absorbed by plants in labile tissues, such as leaves and fine roots $[\underline{56}, \underline{30}, \underline{57} \underline{58}, \underline{46}]$. 


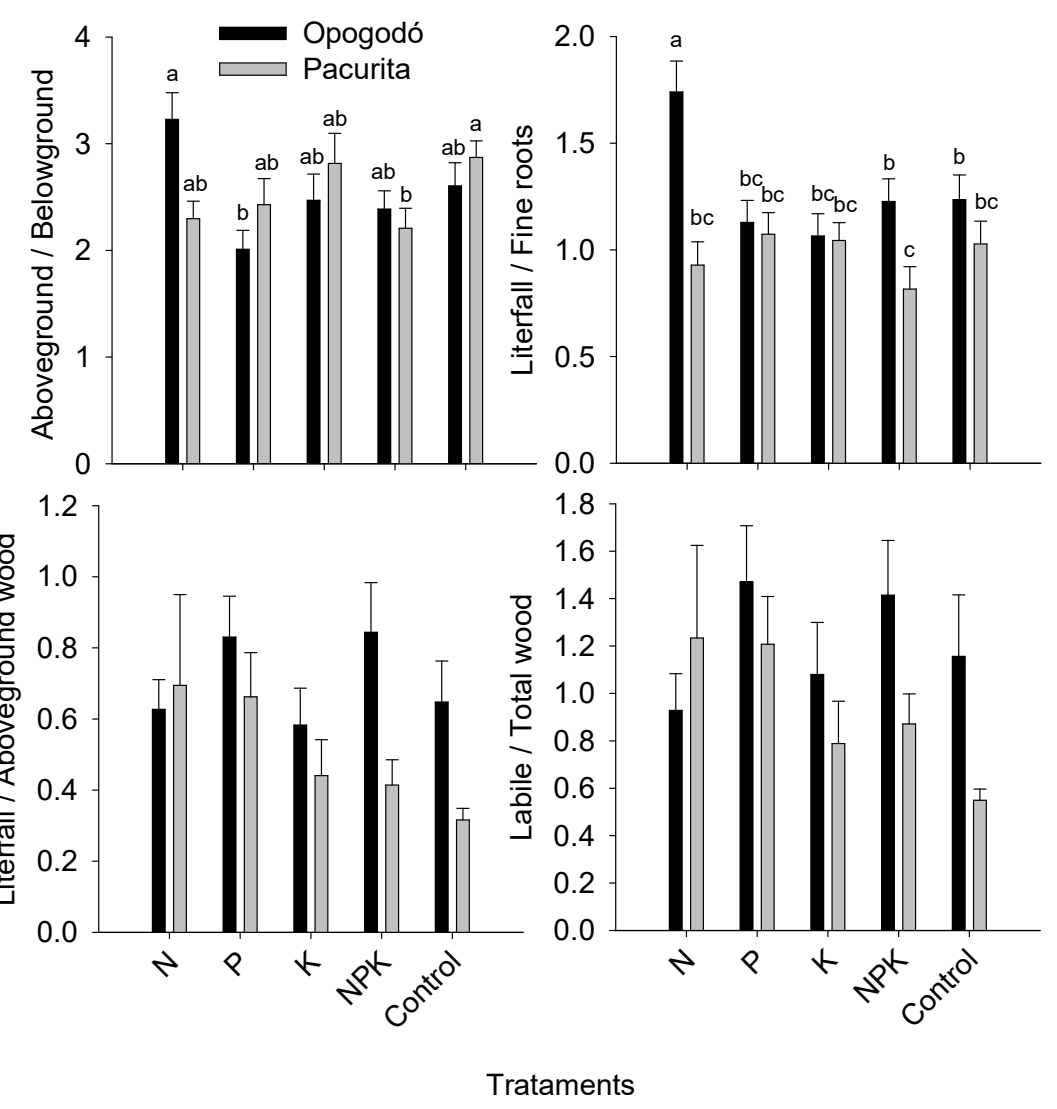

Figure 2. Proportional relation among the components of NPP in tropical rain forests of the Chocó region, Colombia. Different letters indicate statistically significant differences between treatment levels $(\mathrm{P}<0.05)$.

$\mathrm{N}$ application did not show effects on total NPP possibly because the high concentration of total $\mathrm{N}$ in the studied soils [24] resultant of the high biological fixation from the abundance of legumes in these forests $[\underline{59}, \underline{23}]$; it might also be the joint result of the reduction in the decomposition rates of soil organic matter, mineralization of organic $\mathrm{N}$ and $\mathrm{P}$, and nitrification due to the high rainfall $[\underline{25}, \underline{26}, \underline{27}]$.

Although these soils are poor in available P [24], the lack of effect of the $\mathrm{P}$ application on total NPP is probably due to adaptive strategies developed by plants in these ecosystems that allow them to obtain the required edaphic P for its establishment and growth [60]; among them, the mycorrhizae increase the area of nutrient capture, the solubilization of $\mathrm{P}$ retained in $\mathrm{Fe}$ and $\mathrm{Al}$ sesquioxides of soil $[\underline{61}, \underline{62}]$ and the formation of root structures "cluster roots" that release carboxylates in the rhizosphere, which solubilize the scarcely available edaphic P $[\underline{60}, \underline{62}]$. Likewise, the increase in the activity of phosphatase enzymes, released by plants and microorganisms, allow the absorption of $\mathrm{P}$ from soil organic matter [14]. These strategies could also explain the effect of $P$ fertilization on the increased belowground NPP, which will be further discussed.

The lack of effect of K fertilization on total NPP probably comes from its high solubility and easy leaching from the soil, even more than other macronutrients such as $\mathrm{N}$ or $\mathrm{P}[\underline{63}, 17]$; therefore, its edaphic availability decreases with high rainfall [22]. For the same reasons, this mineral shows large depositions to the soil by foliar leaching $[\underline{64}, \underline{65}, \underline{26}]$. Consequently, despite the low content of $\mathrm{K}$ in the soils [Table 1 ], it should not be limiting the NPP in these forests. 

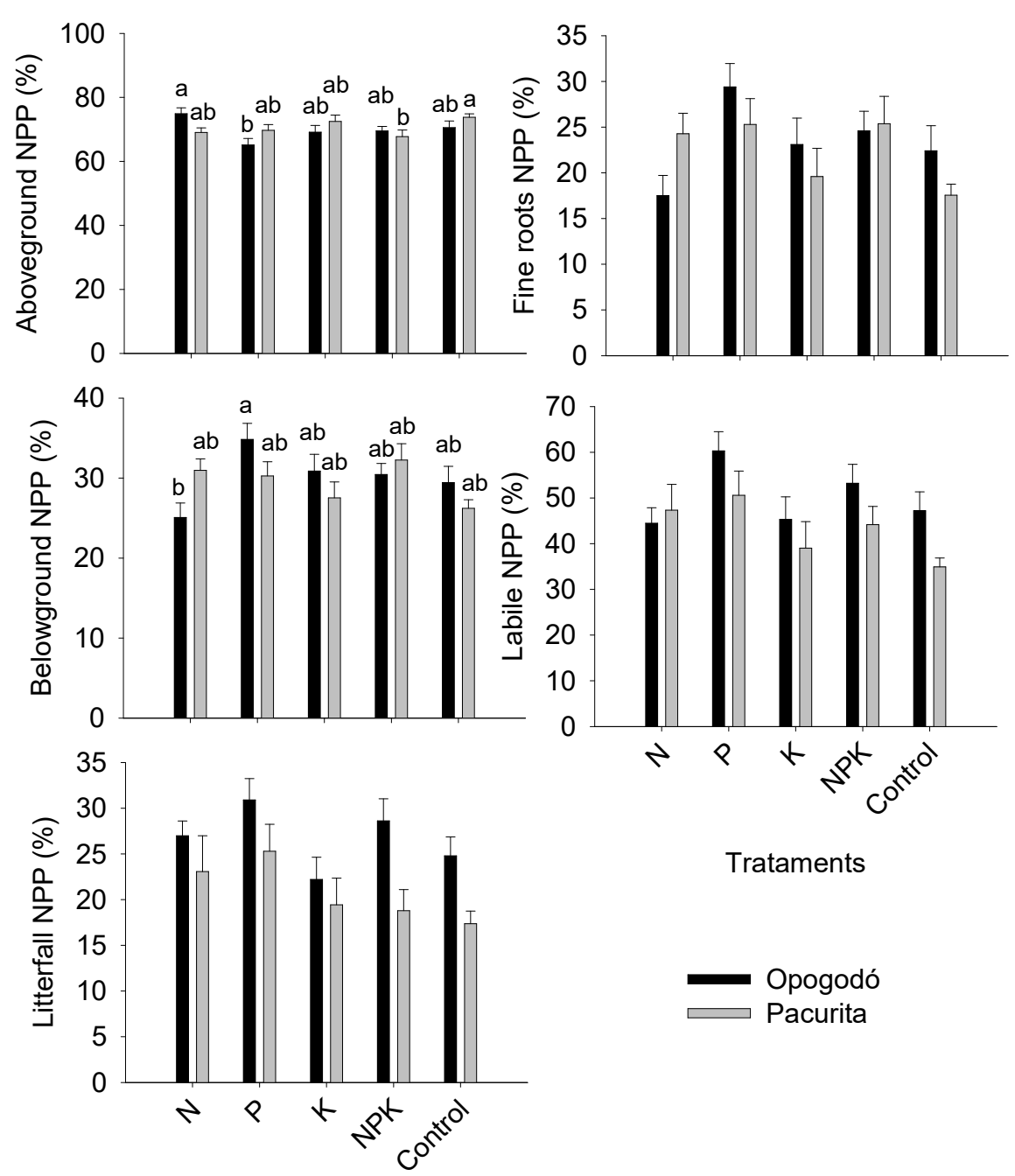

Trataments

Trataments

Figure 3. NPP components in relation to total NPP in tropical rain forests of the Chocó region, Colombia. Different letters indicate statistically significant differences between treatment levels $(\mathrm{P}<0.05)$.

3) Ecophysiological responses of tropical trees: the application of nutrients (N, P and K) produces short-term and long-term eco-physiological responses in tropical trees [미] Among the first ones are the increase in foliar content of nutrients, maximum photosynthetic rate, stomatal conductance, transpiration and water use efficiency; among the longterm responses are the decrease of leaf expansion and nutrient capture capacity, increase of tree growth and production, specific hydraulic conductivity of the stem and leaves, water potential of the xylem, and changes in root biomass and mycorrhizal colonization [50]. These responses to the application of nutrients could also be modified by other limiting factors, such as light, temperature, and soil aeration $[\underline{25}, \underline{26}, \underline{27}]$. In particular, the cloudy skies typical of this rainy region, could be an important factor in decreasing the solar radiation received by forests. Consequently, the combination of the eco-physiological responses possibly explain that the effects of nutrient application at the forest community level are more difficult to detect even in experiments longer than a few years $[\underline{4}, \underline{51}, \underline{46}]$. The effects would be even more diluted when considering that the limitation of NPP for 
each nutrient can be different $[\underline{60}, \underline{18}, \underline{19}]$, and that the ecosystem could be limited by more than one factor $[\underline{30}, \underline{66}, \underline{49}]$.

Effects of fertilization on the above and belowground distribution of forest NPP. It is known that the availability of resources such as water or solar radiation stimulates the allocation of NPP to the above and belowground components of vegetation $[67,68]$. Plants allocate biomass and NPP according to the most limiting resource; for example, more NPP and biomass are allocated to fine roots in soils with limited availability of water and nutrients $[\underline{69}, \underline{70}, \underline{67}, \underline{20}]$. The differential allocation can profoundly affect the ecosystem functioning, since on the one hand, a greater proportion of canopy NPP influences the photosynthetic capacity and the production of flowers and fruits. On the other hand, wood NPP represents the long-term carbon storage in the ecosystem; and finally, fine roots NPP determines the acquisition of water and nutrients from the soil [67].

This hypothesis has received different names, among them, optimal partitioning theory [68], hypothesis of differential allocation [36], hypothesis of balanced growth, and, functional balance of biomass allocation [20]. According to this hypothesis, the responses to the application of nutrients should exhibit a redistribution of NPP among its components, as a strategy of utilization of the additional resources [4]. This is the response evidenced in the present study, where the application of N and P increased the litter NPP and the addition of $\mathrm{P}$ also increased the percentages of belowground NPP, labile material, fine roots and fine litter, but it had no effect on total NPP.

In tropical rainforests, the few studies that have evaluated the above and belowground components of NPP with respect to the edaphic availability of nutrients $[\underline{9}, \underline{11}, \underline{12}]$ report variable results. Aragão et al. $(\underline{12})$, found that total and root NPP increased with the available soil $\mathrm{P}$, in accordance with the hypothesis of the belowground NPP limitation by the edaphic P []]. Contrarily, Quinto-Mosquera and Moreno (11), in the same forests of this study, found correlations that explain variations in the above and belowground components of NPP with the availability of nutrients, less the available P; however, the relationship between the availability of nutrients and total NPP was not significant. The increase in the belowground NPP with the availability of soil nutrients (organic matter, $\mathrm{N}, \mathrm{K}$ and $\mathrm{Mg}$ ) in that study, showed a possible redistribution of the above and belowground NPP components with soil fertility, probably as a mechanism to capture resources in oligotrophic soils [11]. Our results with the application of $P$ are similar in the sense that it increased the belowground and the percentage of labile components of NPP (fine litter and fine roots).

Studies on the effects of fertilization in tropical rainforests show that NPP responses can be differential according to the NPP component measured and the nutrients evaluated

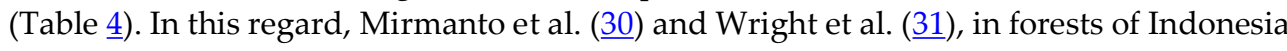
and Panama, respectively, showed increases in fine litter NPP with the application of nutrients $(\mathrm{N}, \mathrm{P}$, and $\mathrm{N}+\mathrm{P})$, but did not show significant changes in tree diameter growth rates. Similarly, Sayer et al. (72) observed an increase of fine litter NPP with the application of $\mathrm{N}, \mathrm{P}$, and organic matter. Contrarily, other investigations did not detect changes in fine litter NPP with the application of nutrients $[\underline{56}, \underline{73}, \underline{49}]$. On the other hand, increases in growth rates of small trees $(5-10 \mathrm{~cm}$ of $\mathrm{DBH})$ with the application of $\mathrm{P}$ were reported, but effects on fine roots or litterfall NPP were not identified [ $\underline{49}, \underline{58}]$. Despite these results show the variability and complexity of NPP responses to fertilization, the present study experimentally proves that fertilization generated a redistribution of the above and belowground components of NPP.

Final remarks. Most tropical forests are characterized by high NPP rates $[2,1]$ despite they grow on poor soils, characterized by low nutrient concentrations [ $\underline{4}, \underline{15}]$; for this reason, these ecosystems are thought to be limited by nutrients such as $\mathrm{N}, \mathrm{P}$ and $\mathrm{K}$ $[\underline{7}, \underline{10}, \underline{12}, \underline{8}, \underline{6}]$. However, the results of the present study experimentally demonstrated that total NPP was not limited by the availability of N, P and K in tropical pluvial forests of the biogeographic Chocó. Contrarily, a redistribution of the above and belowground NPP 
with the application of nutrients was found; especially $\mathrm{P}$, which increased the proportion of belowground and labile (fine roots and fine litter) and decreased the woody components of forest NPP. This is a possible mechanism to capture added nutrients, such as P, which in these soils are scarcely available.

Table 4. Studies on the effects of soil fertilization on NPP components in mature tropical rainforests.

\begin{tabular}{|c|c|c|c|c|c|c|c|}
\hline Sites & $\begin{array}{c}\text { Nutrients } \\
\text { applied }\end{array}$ & Litterfall & $\begin{array}{c}\text { Aboveground } \\
\text { biomass }\end{array}$ & $\begin{array}{l}\text { Coarse } \\
\text { roots }\end{array}$ & $\begin{array}{l}\text { Fine } \\
\text { roots }\end{array}$ & $\begin{array}{l}\text { Total } \\
\text { NPP }\end{array}$ & References \\
\hline \multirow{3}{*}{ Tierra Firme. Amazonia. Brasil } & $\mathrm{NH} 4 \mathrm{Cl}$ & $\mathrm{ND}^{1}$ & ND & ND & No effect & ND & \multirow{9}{*}{ 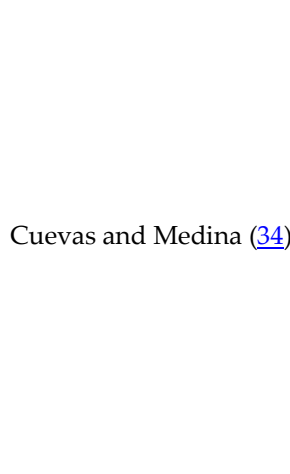 } \\
\hline & KH2PO4 & ND & ND & ND & Positive & ND & \\
\hline & $\mathrm{CaCl} 2$ & ND & ND & ND & Positive & ND & \\
\hline \multirow{3}{*}{ Tall Caatinga. Amazonia. Brasil } & $\mathrm{NH} 4 \mathrm{Cl}$ & ND & ND & ND & Positive & ND & \\
\hline & $\mathrm{KH} 2 \mathrm{PO} 4$ & ND & ND & ND & No effect & ND & \\
\hline & $\mathrm{CaCl} 2$ & ND & ND & ND & No effect & ND & \\
\hline \multirow{3}{*}{ Low Bana. Amazonia. Brasil } & $\mathrm{NH} 4 \mathrm{Cl}$ & ND & ND & ND & Positive & ND & \\
\hline & KH2PO4 & ND & ND & ND & Positive & ND & \\
\hline & $\mathrm{CaCl} 2$ & ND & ND & ND & No effect & ND & \\
\hline & $\mathrm{N}$ & Positive & No effect & ND & ND & ND & \multirow{3}{*}{ Mirmanto et al. $(\underline{30})$} \\
\hline Indonesia & $\mathrm{P}$ & Positive & No effect & ND & ND & ND & \\
\hline & NP & Positive & No effect & ND & ND & ND & \\
\hline Luquillo Forest. Puerto Rico & $\mathrm{N}$ & No effect & No effect & ND & ND & ND & Cusack et al. (프) \\
\hline \multirow{7}{*}{$\begin{array}{l}\text { Barro } \\
\text { Panama }\end{array}$} & $\mathrm{N}$ & No effect & No effect & ND & ND & ND & \multirow{7}{*}{ Wright et al. (1ㅡ) } \\
\hline & $\mathrm{P}$ & Positive & No effect & ND & ND & ND & \\
\hline & K & No effect & No effect & ND & ND & ND & \\
\hline & NPK & No effect & No effect & ND & ND & ND & \\
\hline & $\mathrm{NP}$ & No effect & No effect & ND & ND & ND & \\
\hline & NK & No effect & Positive & ND & ND & ND & \\
\hline & PK & No effect & No effect & ND & ND & ND & \\
\hline \multirow{3}{*}{$\begin{array}{l}\text { Lowland tropical wet forest } \\
\text { Costa Rica }\end{array}$} & $\mathrm{N}$ & No effect & No effect & ND & No effect & ND & \multirow{3}{*}{ 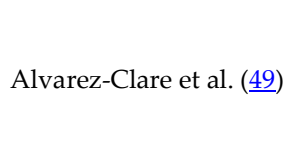 } \\
\hline & $\mathrm{P}$ & No effect & Positive & ND & No effect & ND & \\
\hline & NP & No effect & Positive & ND & No effect & ND & \\
\hline \multirow{3}{*}{ Tambopata, Amazon Perú } & $\mathrm{N}$ & ND & No effect & ND & ND & ND & \multirow{3}{*}{ Fisher et al. $(\underline{74})$} \\
\hline & $P$ & ND & No effect & ND & ND & ND & \\
\hline & NP & ND & Positive & ND & ND & ND & \\
\hline
\end{tabular}

${ }^{1} \mathrm{ND}$ : undetermined

Author Contributions: Conceptualization, H.Q.M. and F.M.; methodology, H.Q.M.; formal analysis, H.V.C.; investigation, H.Q.M.; resources, H.Q.M. and F.M.; data curation, H.Q.M. and F.M.; writing - original draft preparation, H.Q.M.; writing - review and editing, H.Q.M. and F.M.; visualization, F.M.; supervision, F.M.; project administration, H.Q.M.; funding acquisition, H.Q.M.; All authors have read and agreed to the published version of the manuscript.

Funding: This study was financed by the Departamento Administrativo de Ciencia, Tecnología e Innovación de Colombia - COLCIENCIAS (http://www.colciencias.gov.co), the Universidad Tecnológica del Chocó "Diego Luis Córdoba" (http://www.utch.edu.co/portal/es), and the Universidad Nacional de Colombia sede Medellín (http://medellin.unal.edu.co). This research was funded through the Project "Evaluación del efecto de la fertilización del suelo sobre la producción neta del ecosistema 
en áreas degradadas por minería, como estrategia para potenciar la captura de carbono y la venta de servicios ambientales en el Chocó biogeográfico", code 1128 -852-72243, contract 494-2020.

Acknowledgments: We are grateful with Dr. J. Wright for reviewing the manuscript. Likewise, we thank Monica Minotta, Lehner Córdoba, Jefferson Córdoba, and Yeison Rivas, for their support in the field activities. We are also acknowledged by the hospitality and collaboration of the inhabitants of the locality of Opogodó (municipality of Condoto) and Pacurita (municipality of Quibdó).

Conflicts of Interest: The authors declare no conflict of interest. Authors must identify and declare any personal circumstances or interest that may be perceived as inappropriately influencing the representation or interpretation of reported research results. The funders had no role in the design of the study; in the collection, analyses, or interpretation of data; in the writing of the manuscript, or in the decision to publish the results.

\section{References}

1. Saugier, B.; Roy, J.; Mooney, H.A. Estimations of global terrestrial productivity: converging toward a single number? In Terrestrial Global Productivity, Roy, J.; Saugier, B.; Mooney, H.A., Eds.; Academic Press. San Diego, USA, 2001, pp. 543-557.

2. Pan, Y.; Birdsey, R.A.; Fang, J.; Houghton, R.; Kauppi, P.E.; Kurz, W.A.; et al. A large and persistent carbon sink in the world's forests. Science 2011, 333(6045):988-993. https://doi: 10.1126/science.1201609

3. Clark, D.A.; Brown, S.; Kicklighter, D.W.; Chambers, J.D.; et al. Measuring net primary production in forests: concepts and field methods. Ecological Applications 2001a, 11, 356-370. https://doi.org/10.1890/1051-0761(2001)011[0356:MNPPIF]2.0.CO;2

4. Chapin III, F.S.; Vitousek, P.M.; Van Cleve, K. The Nature of Nutrient Limitation in Plant Communities. The American Naturalist 1986, 127(1), 48-58. https://doi.org/10.1086/284466

5. Baillie, I.C. Soils of the humid tropics. In The tropical rain forest, Richards, P.W., Ed.; New York, Cambridge University Press, Cambridge, 1996, pp 256-285.

6. Wieder, W.R.; Cleveland, C.C.; Smith, W.K.; Todd-Brown, K. Future productivity and carbon storage limited by terrestrial nutrient availability. Nature Geoscience 2015, 8, 441-444. https://www.nature.com/articles/ngeo2413

7. Vitousek, P.M. Litterfall, nutrient cycling, and nutrient limitation in tropical forests. Ecology 1984, 65(1), 285-298. https://doi.org/10.2307/1939481

8. Cleveland, C.C.; Townsend, A.R.; Taylor, P.; Alvarez-Clare, S.; Bustamante, M.; Chuyong, G.; Dobrowski, S.Z.; Grierson, P.; Harms, K.E.; et al. Relationships among net primary productivity, nutrients and climate in tropical rain forest: a pan-tropical analysis. Ecology Letter 2011, 14, 939-947. https://doi.org/10.1111/j.1461-0248.2011.01658.x

9. Jiménez, E.M.; Peñuela-Mora, M.C.; Sierra, C.A.; Lloyd, J.; Phillips, O.L.; Moreno, F.H.; Quesada, C.A. Edaphic controls on ecosystem-level carbon allocation in two contrasting Amazon forests. Journal of Geophysical Research: Biogeosciences 2014, 119(9), 18201830. https://doi.org/10.1002/2014JG002653

10. Paoli, G.D.; Curran, L.M. Soil nutrients limit fine litter production and tree growth in mature lowland forest of southwestern Borneo. Ecosystems 2007, 10(3), 503-518. https://doi.org/10.1007/s10021-007-9042-y

11. Quinto-Mosquera, H.; Moreno-Hurtado, F. Net primary productivity and edaphic fertility in two pluvial tropical forests in the Chocó biogeographical region of Colombia. PLoS ONE 2017, 12(1): e0168211. https://doi.org/10.1371/journal.pone.0168211

12. Aragão, L.E.O.; Malhi, Y.; Metcalfe, D.B.; Silva-Espejo, J.E.; Jiménez, E.; Navarrete, D.; Almeida, S.; Costa, A.C.L.; Salinas, N.; Phillips, O.L.; et al. Above- and below-ground net primary productivity across ten Amazonian forests on contrasting soils. Biogeosciences 2009, 6, 2441-2488. https://doi.org/10.5194/bg-6-2759-2009

13. Walker, T.W.; Syers, J.K. The fate of phosphorus during pedogenesis. Geoderma 1976, 15(1), 1-19. https://doi.org/10.1016/0016$\underline{7061(76) 90066-5}$

14. Vitousek, P.M.; Porder, S.; Houlton, B.Z.; Chadwick, O.A. Terrestrial phosphorus limitation: mechanisms, implications, and nitrogen-phosphorus interactions. Ecological Applications 2010, 20(1), 5-15. https://doi.org/10.1890/08-0127.1

15. Vitousek, P.M.; Sanford, Jr, R.L. Nutrient cycling in moist tropical forest. Annual Review of Ecology and Systematics 1986, 17, 137167. https://doi.org/10.1146/annurev.es.17.110186.001033

16. Tripler, C.E.; Kaushal, S.S.; Likens, G.E.; Walter, M.T. Patterns in potassium dynamics in forest ecosystems. Ecology Letters 2006, 9, 451-466. https://doi.org/10.1111/j.1461-0248.2006.00891.x

17. Sardans, J.; Peñuelas, J. Potassium: a neglected nutrient in global change. Global Ecology and Biogeography 2015, 24, 261-275. https://doi.org/10.1111/geb.12259

18. Sullivan, B.W.; Alvarez-Clare, S.; Castle, S.C.; Porder, S.; Reed, S.C.; Schreeg, L. Assessing nutrient limitation in complex forested ecosystems: alternatives to large-scale fertilization experiments. Ecology 2014, 95(3), 668-681. https://doi.org/10.1890/13-0825.1

19. Sayer, E.J.; Banin, L.F. Tree nutrient status and nutrient cycling in tropical forest-Lessons from fertilization experiments. In Tropical tree physiology. Adaptations and responses in a changing environment, Goldstein, G.; Santiago, L.S., Eds.; Springer International Publishing Switzerland, 2016; pp. 275-297.

20. Poorter, H.; Niklas, K.J., Reich, P.B.; Oleksyn, J.; Poot, P.; Mommer, L. Biomass allocation to leaves, stems and roots: meta-analyses of interspecific variation and environmental control. New Phytologist 2012, 193(1), 30-50. https://doi.org/10.1111/j.14698137.2011.03952.x 
21. Schuur, E.A.G. Net primary productivity and global climate revisited: the sensitivity of tropical forest growth to precipitation. Ecology 2003, 84(5), 1165-1170. https://doi.org/10.1890/0012-9658(2003)084[1165:PAGCRT]2.0.CO;2

22. Austin, A.T.; Vitousek, P.M. Nutrient dynamics on a precipitation gradient in Hawai'i. Oecologia 1998, 113(4), 519-529. https://doi.org/10.1007/s004420050405

23. Posada, J.M.; Schuur, E.A.G. Relationships among precipitation regime, nutrient availability, and carbon turnover in tropical rain forests. Oecologia 2011, 165, 783-795. https://doi.org/10.1007/s00442-010-1881-0

24. Quinto-Mosquera, H.; Moreno-Hurtado, F. Precipitation effects on soil characteristics in tropical rain forests of the Chocó biogeographical region. Revista Facultad Nacional de Agronomía Medellín 2016, 69(1), $7813-7823$. http://dx.doi.org/10.15446/rfna.v69n1.54749

25. Schuur, E.A.G.; Matson, P.A. Net primary productivity and nutrient cycling across a mesic to wet precipitation gradient in Hawaiian montane forest. Oecologia 2001, 128, 431-442. https://doi.org/10.1007/s004420100671

26. Santiago, L.S.; Schuur, E.A.G.; Silvera, K. Nutrient cycling and plant-soil feedbacks along a precipitation gradient in lowland Panama. Journal Tropical Ecology 2005, 21(4), 461-470. https://doi.org/10.1017/S0266467405002464

27. Alvarez-Clare, S.; Mack, M.C. Influence of precipitation on soil and foliar nutrients across nine Costa Rican forests. Biotropica 2011, 43, 433-441. https://doi.org/10.1111/j.1744-7429.2010.00732.x

28. Poveda, M.C.; Rojas, C.; Rudas, A.; Rangel, O. El Chocó biogeográfico: Ambiente Físico. En Colombia Diversidad Biótica IV. El Chocó biogeográfico/ Costa Pacífica. Rangel, O. Ed.; Instituto de Ciencias Naturales. Universidad Nacional de Colombia. Bogotá, Colombia, 2004, pp1024.

29. Shieh, G.; Jan, S. The effectiveness of randomized complete block design. Statistica Neerlandica 2004, 58(1), 111-124. https://doi.org/10.1046/j.0039-0402.2003.00109.x

30. Mirmanto, E.; Proctor, J.; Green, J.; Nagy, L.; Suriantata. Effects of nitrogen and phosphorus fertilization in a lowland evergreen rainforest. Philosophical Transactions of the Royal Society B 1999, 354, 1825-1829. https://doi.org/10.1098/rstb.1999.0524

31. Wright, S.J.; Yavitt, J.B.; Wurzburger, N.; Turner, B.L.; Tanner, E.V.J.; Sayer, E.J.; Santiago, L.S.; Kaspari, M.; Hedin, L.O.; Harms, K.E.; Garcia, M.N.; Corre, M.D. Potassium, phosphorus, or nitrogen limit root allocation, tree growth, or litter production in a lowland tropical forest. Ecology 2011, 92(8), 1616-1625. https://doi.org/10.1890/10-1558.1

32. Gentry, A. A field guide to the families and genera of woody plants of Northwest South Amercian (Colombia, Ecuador, Peru). Conservation International, Washington, DC. 20056. USA, 1993, pp. 895

33. Quinto-Mosquera, H.; Moreno-Hurtado, F. Dinámica de la biomasa aérea en un bosque pluvial tropical del Chocó biogeográfico. Revista Facultad Nacional de Agronomía Medellín 2011, 64(1), 5917-5936. http://www.scielo.org.co/scielo.php?script=sci arttext\&pid=S0304-28472011000100016\&lng=en\&nrm=iso

34. Cuevas, E.; Medina, E. Nutrient dynamics within Amazonian forests. II. Fine root growth, nutrient availability and leaf litter decomposition. Oecologia 1988, 76(2), 222-235. https://doi.org/10.1007/BF00379956

35. Moreno-Hurtado, F. Soil carbon dynamics in primary and secondary tropical forests in Colombia. Thesis of Doctor of Philosophy in Biology. Florida International University. Miami. Florida. USA. 2004, pp. 208

36. Hendricks, J.; Hendricks, R.L.; Wilson, C.A.; Mitchell, R.J.; Pecot, S.D.; Guo, D. Assessing the patterns and controls of fine root dynamics: an empirical test and methodological review. Journal of Ecology 2006, 94, 40-57. https://besjournals.onlinelibrary.wiley.com/doi/pdf/10.1111/j.1365-2745.2005.01067.x

37. Brown, S. Estimating biomass and biomass change of tropical forests: A primer. Food and Agriculture Organization, UN FAO Forestry Paper, no. 134, Roma, 1997; http://www.fao.org/3/w4095e/w4095e00.htm

38. Baker, T.R.; Phillips, O.L.; Malhi, Y.; Almeida, S.; Arroyo, L.; Di Fiore, A.; Erwin, T.; Killeen, T.J.; Laurance, S.G.; Laurance, W.F.; Lewis, S.L.; Lloyd, J.; Monteagudo, A.; Neill, D.A.; Patiño, S.; Pitman, N.A.; Silva, J.N.M.; Vasquez, M.R. Variation in wood density determines spatial patterns in amazonian forest biomass. Global Change Biology 2004, 10, 545-562. https://doi.org/10.1111/j.13652486.2004.00751.x

39. Chave, J.; Andalo, C.; Brown, S.; Cairns, M.A.; Chambers, J.Q.; Eamus, D.; Folster, H.; Fromard, F.; Higuchi, N.; Kira, T.; Lescure, J.P.; Nelson, B.W.; Ogawa, H.; Puig, H.; Riera, B.; Yamakura, T. Tree allometry and improved estimation of carbon stocks and balance in tropical forests. Oecologia 2005, 145, 87-99. https://doi.org/10.1007/s00442-005-0100-x

40. Clark, D.A.; Brown, S.; Kicklighter, D.W.; Chambers, J.D.; et al. Net primary production in forests: an evaluation and synthesis of existing field data. Ecological Applications 2001b, 11, 371-384. https://doi.org/10.1890/1051-0761(2001)011[0371:NPPITF]2.0.CO;2

41. Chapin III, F.S.; Woodwell, G.M.; Randerson, J.T.; Rastetter, E.B.; Lovett, G.M.; Baldocchi, D.D.; Clark, D.A.; Harmon, M.E.; Schimel, D.S. et al. Reconciling Carbon-cycle Concepts, Terminology, and Methods. Ecosystems 2006, 9, $1041-1050$. https://doi.org/10.1007/s10021-005-0105-7

42. Sierra, C.A.; Harmon, M.E.; Moreno, F.H.; Orrego, S.A.; Del Valle, J.I. Spatial and temporal variability of net ecosystem production in a tropical forest: testing the hypothesis of a significant carbon sink. Global Change Biology 2007, 13(1), 838-853. https://doi.org/10.1111/j.1365-2486.2007.01336.x

43. R Core Team. R: A language and environment for statistical computing. R Foundation for Statistical Computing, Vienna, Austria, 2012, Recuperado de http://www.R-project.org/

44. Pinheiro, J.; Bates, D.; DebRoy, S.; Sarkar, D.; Heisterkamp, S.; Van Willigen, B. Linear and Nonlinear Mixed Effects Models. 2018, Recuperado de: https://cran.r-project.org/web/packages/nlme/nlme.pdf.

45. Lebauer, D.S.; Treseder, K.K. Nitrogen limitation of net primary productivity in terrestrial ecosystems is globally distributed. Ecology 2008, 89(2), 371-379. https://doi.org/10.1890/06-2057.1 
46. Wright, S.J.; Turner, B.L.; Yavitt, J.B.; Harms, K.E.; Kaspari, M.; Tanner, E.V.; Bujan, J.; Griffin, E.A.; Mayor, J.R.; Pasquini, S.C.; Sheldrake, M.; Garcia, M.N. Plant responses to fertilization experiments in lowland, species-rich, tropical forests. Ecology 2018, 99(5), 1129-1138. https://doi.org/10.1002/ecy.2193

47. Faber-Langendoen, D.; Gentry, A.H. The structure and diversity of rain forests at BajoCalima, Chocó Region, western Colombia. Biotropica 1991, 23(1), 2-11. https://doi:10.2307/2388682

48. Quinto-Mosquera, H.; Moreno-Hurtado, F. Diversidad florística arbórea y su relación con el suelo en un bosque pluvial tropical del Chocó biogeográfico. Revista Árvore 2014, 38(6), 1123-1132. http://dx.doi.org/10.1590/S0100-67622014000600017

49. Alvarez-Clare, S; Mack, M.C.; Brooks, M. A direct test of nitrogen and phosphorus limitation to net primary productivity in a lowland tropical wet forest. Ecology 2013, 94, 1540-1551. https://doi.org/10.1890/12-2128.1

50. Santiago, L.S. Nutrient limitation of eco-physiological processes in tropical trees. Trees 2015, 29(5), 1291-1300. https://doi.org/10.1007/s00468-015-1260-x

51. Santiago, L.S.; Wright, S.J.; Harms, K.E.; Yavitt, J.B.; Korine, C.; Garcia, M.N.; Turner, B.L. Tropical tree seedling growth responses to nitrogen, phosphorus and potassium addition. Journal of Ecology 2012, 100, 309-316. https://doi.org/10.1111/j.13652745.2011.01904.x

52 Richardson, A.E.; Simpson, R.J. Soil Microorganisms Mediating Phosphorus Availability. Plant Physiology 2011, 156, 989-996. https://doi.org/10.1104/pp.111.175448

53. Gyaneshwar, P.; Naresh Kumar, G.; Parekh, L.J.; Poole, P.S. Role of soil microorganisms in improving P nutrition of plants. Plant and Soil 2002, 245, 83-93. https://doi.org/10.1023/A:1020663916259

54. Olander, L.P.; Vitousek, P.M. Biological and geochemical sinks for phosphorus in soil from a wet tropical forest. Ecosystems 2004, 7, 404-419. https://doi.org/10.1007/s10021-004-0264-y

55. Dalling, J.; Heineman, K.; Lopez, O.; Wright, S.J.; Turner, B. Nutrient Availability in Tropical Rain Forests: The Paradigm of Phosphorus Limitation. In Tropical Tree Physiology, Goldstein, G., Santiago, L.S., Eds.; Springer International Publishing Switzerland. 2016; pp 261-273.

56. Newbery, D.M.; Chuyong, G.B.; Green, J.J.; Songwe, N.C.; Tchuenteu, F.; Zimmermann, L. Does low phosphorus supply limit seedling establishment and tree growth in groves of ectomycorrhizal trees in a central African rainforest? New Phytologist 2002, 156, 297-311. https://doi.org/10.1046/j.1469-8137.2002.00505.x

57. Mayor, J.R.; Wright, S.J.; Turner, B.L. Species-specific responses of foliar nutrients to long-term nitrogen and phosphorus additions in a lowland tropical forest. Journal of Ecology 2014, 102, 36-44. https://doi.org/10.1111/1365-2745.12190

58. Alvarez-Clare, S.; Mack, M.C. Do Foliar, Litter, and Root Nitrogen and Phosphorus Concentrations Reflect Nutrient Limitation in a Lowland Tropical Wet Forest? PLoS ONE 2015, 10(4):e0123796. https://doi.org/10.1371/journal.pone.0123796

59. Cleveland, C.C.; Townsend, A.R.; Schimel, D.S.; Fisher, H.; Howarth, R.W.; Hedin, L.O.; Perakis, S.S.; Latty, E.F.; Von Fischer, J.C.; Elseroad, A.; Wasson, M.F. Global patterns of terrestrial biological nitrogen (N2) fixation in natural ecosystems. Global Biogeochemical Cycles 1999, 13(2), 623-645. https://doi.org/10.1029/1999GB900014

60. Lambers, H.; Raven, J.A.; Shaver, G.R.; Smith, S.E. Plant nutrient-acquisition strategies change with soil age. Trends in Ecology and Evolution 2008, 23 (2), 95-103. https://doi.org/10.1016/j.tree.2007.10.008

61. Finlay, R.D. Ecological aspects of mycorrhizal symbiosis: with special emphasis on the functional diversity of interactions involving the extraradical mycelium. Journal of Experimental Botany 2008, 59(5), 1115-1126. https://doi.org/10.1093/jxb/ern059

63. Boxman, A.W.; Cobben, P.L.W.; Roelofs, J.G.M. Does (K+Mg+Ca+P) fertilization lead to recovery of tree health in a nitrogen stressed Quercus rubra L. stand? Environmental Pollution 1985, 85, 297-303. https://doi.org/10.1016/0269-7491(94)90051-5

64. Duchesne, L.; Ouimet, R.; Camire, C.; Houle, D. Seasonal nutrient transfers by foliar resorption, leaching, and litter fall in a northern hardwood forest at Lake Clair watershed, Quebec, Canada. Canadian Journal of Forest Research 2001, 31, 333-344. https://doi.org/10.1139/x00-183

62. Smith, S.E.; Read, D.J. Mycorrhizal Symbiosis. 3rd Edition. Academic Press. Elsevier, 2008; pp 800.

65. Kopacek, J.; Turek, J.; Hejzlar, J.; Santruckova, H. Canopy leaching of nutrients and metals in a mountain spruce forest. Atmospheric Environment 2009, 43, 5443-5453. https://doi.org/10.1016/j.atmosenv.2009.07.031

66. Kaspari, M.; Garcia, M.N.; Harms, K.E.; Santana, M.; Wright, S.J.; Yavitt, J.B. Multiple nutrients limit litterfall and decomposition in a tropical forest. Ecology Letters 2008, 11(1), 35-43. https://doi.org/10.1111/j.1461-0248.2007.01124.x

67. Malhi, Y.; Doughty, C.; Galbraith, D. The allocation of ecosystem net primary productivity in tropical forests. Philosophical Transactions of the Royal Society B 2011, 366, 3225-3245. https://doi.org/10.1098/rstb.2011.0062

68. Jhm, T. A balanced quantitative model for root:shoot allocation ratios in vegetative plants. Annals of Botany 1972, 36(2), $431-441$. https://doi.org/10.1093/oxfordjournals.aob.a084602

69. Bloom, A.J.; Chapin, III F.S.; Mooney, H.A. Resource limitation in plants-an economic analogy. Annual Review of Ecology and Systematics 1985, 16, 363-392. https://doi.org/10.1146/annurev.es.16.110185.002051

70. Aerts, R.; Chapin III, F.S. The Mineral Nutrition of Wild Plants Revisited: A Re-evaluation of Processes and Patterns. Advances in Ecological Research 2000, 30, 1-67. http://dx.doi.org/10.1016/S0065-2504(08)60016-1

71. Portsmuth, A.; Niinemets, U. Structural and physiological plasticity in response to light and nutrients in five temperate deciduous woody species of contrasting shade tolerance. Functional Ecology 2007, 21, 61-77. https://doi.org/10.1111/j.1365-2435.2006.01208.x

72. Sayer, E.J.; Wright, S.J.; Tanner, E.V.J.; Yavitt, J.B.; Harms, K.E.; Powers, J.S.; Kaspari, M.; Garcia, M.N.; Turner, B.L. Variable responses of lowland tropical forest nutrient status to fertilization and litter manipulation. Ecosystems 2012, 15(3), 387-400. https://doi.org/10.1007/s10021-011-9516-9 
73. Cusack, D.F.; Silver, W.L.; Torn, M.S.; McDowell, W.H. Effects of nitrogen additions on above and belowground carbon dynamics in two tropical forests. Biogeochemistry 2011, 104(1), 203-225. https://doi.org/10.1007/s10533-010-9496-4

74. Fisher, J.B.; Malhi, Y.; Torres, I.C.; Metcalfe, D.B.; van de Weg, M.J.; Meir, P.; Silva-Espejo, J.E.; Huasco, W.H. Nutrient limitation in rainforests and cloud forests along a 3,000-m elevation gradient in the Peruvian Andes. Oecologia 2013, 172(3), 889-902. https://doi.org/10.1007/s00442-012-2522-6 